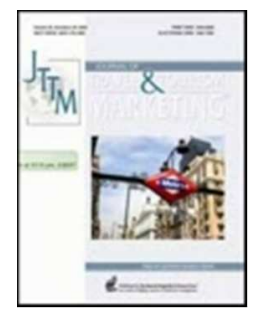

\title{
Residents' attitudes and behavioural support for tourism in host communities
}

\begin{tabular}{|r|l|}
\hline Journal: & Journal of Travel \& Tourism Marketing \\
\hline Manuscript ID & WTTM-2016-0358.R2 \\
\hline Manuscript Type: & Full-length Article \\
\hline Keywords: & Residents, Attitudes, Perceptions, Behavioural support, Host communities \\
\hline \multicolumn{2}{|c}{} \\
\hline
\end{tabular}

SCHOLARONE $^{\text {"x }}$
Manuscripts 


\title{
Residents' attitudes and behavioural support for tourism in host communities
}

\begin{abstract}
In our study of the 'perceptions-attitudes-behaviours' sequence, we explain how resident perceptions of tourism's impacts in host communities influence not only their attitudes towards tourism, but also their attitudes towards tourists - i.e. a new variable that has recently introduced in literature-. Moreover, we introduce the behavioural support, a concept that denotes a higher level of involvement and engagement of residents with their communities in comparison with the traditional attitudinal support. Our results indicate: 1) the residents' perception of the positive economic and cultural impacts of tourism are the main variables influencing their attitudes towards tourism and tourists; and 2) both types of attitudes influence on behavioural support for tourism in host communities.
\end{abstract}

\section{Keywords:}

Host communities; residents; attitudes; perceptions; behavioural support. 


\section{Journal of Travel \& Tourism Marketing}

\section{Introduction}

Residents are usually conceived a keystone of tourism development strategies in host communities (Easterling, 2004; Sharpley, 2014). Particularly, Ribeiro, Pinto, Silva \& Woosnam (2017) emphasize the need of attending the needs and concerns of residents to achieve a sustainable tourism development in host communities. Their study mainly bases this argument on the fact that residents will have a behaviour supporting or not tourism depending on their perceptions of the positive and negative impacts of tourism in their communities. For their part, Zhang, Inbakaran \& Jackson (2006) already previously established the relevance of managing these perceptions in order to achieve a more harmonious relationship between tourists and residents, which is considered the central element of tourism (Sharpley, 2014; Yu \& Lee, 2014). More recently, Palmer, Koenig-Lewis \& Medi Jones(2013) have emphasized that residents that are more involved with their communities have a key role as 'ambassadors' since they promote incoming tourism through positive word-of-mouth, which is a very relevant information source for tourists (Litvin, Goldsmith \& Pan, 2008).

Past research has paid special attention to resident perceptions of the economic, sociocultural and environmental impacts of tourism in host communities -for example, Sinclair, Gursoy \& Vieregge (2015), Vargas, Plaza \& Porra (2015) and Wang \& Xu (2015)-, with the purpose of better understanding the nature and formation of this critical issue to be managed in the tourism development strategies of regions and countries. In particular, these perceptions are considered the main driver of resident attitudes towards tourism (Vargas et al., 2015). However, it is necessary to indicate that most previous research have studied resident perceptions and attitudes as overlapping concepts or, even, synonymous (Sharpley, 2014; Sinclair et al., 2015). In our study, following to Vargas et al. (2015), we distinguish between residents' specific perceptions 


\section{Journal of Travel \& Tourism Marketing}

with regard to the positive and negative impacts of tourism activities in their communities and, as a consequence of these perceptions, their overall attitudes concerning the tourism phenomenon. Particularly, attitude is a psychological variable that is considered a more consistent disposition than perceptions. In our context, it specifically refers the resident's enduring predisposition to the tourism in host communities (Ap, 1992).

In this context, our study aims to contribute to the literature by developing a model of resident attitudes that includes not only the attitudes towards tourism, but also those attitudes towards tourists. In particular, most studies have focused on the attitudes towards tourism, which are mainly cognitive in nature, but not on the feelings or affective attitudes towards tourists (Woosnam, Norman \& Ying, 2009). In contrast, these relations (most known as "host-guest interactions") have been widely examined in previous studies on destination image and satisfaction -for example, Bianchi (2016) Herrero, San Martín, García-de los Salmones \& Collado (2016)-, although they adopted the tourists point of view and not from residents. Thus, our study aims to explain how are formed both, the attitudes towards tourism in host communities and the attitudes towards tourists. In line with Woosnam and Norman (2010), this approach would lead to a more comprehensive understanding of the residents' responses to the tourism phenomenon.

In addition, it should be also highlighted that most studies -for example, Garau, Díaz \& Gutiérrez (2014), Vargas et al. (2015), Almeida, Peláez, Balbuena \& Cortés (2016) and Rasoolimanesh, Roldán, Jaafar \& Ramayah (2016)- have focused on examining how resident perceptions and attitudes are influenced by: 1) extrinsic variables, such as seasonality or tourism development; and 2) intrinsic variables, such as demographic characteristics or social identity. However, much more research is needed to examine 
how perceptions and attitudes influence the subsequent responses or behaviours of residents (Sharpley, 2014). In this sense, our study also contributes to the literature by considering the "perceptions-attitudes-behavioural support" sequence in our model of resident attitudes. More concretely, unlike most studies that use the concept of support in an attitudinal sense -for example, Látková and Vogt (2012), Nunkoo and Ramkissoon (2011), Nunkoo and So (2016) and Rasoolimanesh et al. (2016)-, this study goes further by examining the support for tourism from a behavioural approach. In particular, we consider that the residents' participation in tourism activities in their communities, as well as their recommendations about them to other people, are two key behavioural indicators of support for tourism.

\section{Literature review}

We provide some background on the topic under investigation and conceptualize the variables of our theoretical model: resident perceptions of the positive and negative impacts of tourism, attitudes towards tourism and tourists, and behavioural support for tourism in host communities. In addition, we propose the causal relationships among these variables, thus formulating the hypotheses to be tested in our study.

\subsection{Residents' perceptions and attitudes towards tourism}

As observed in Table 1, three main types of impacts of tourism are identified in literature: economic, sociocultural and environmental impacts. Residents will form their perceptions of tourism phenomenon in terms of economic benefits/costs (for example, employment opportunities versus undesirable business activities), sociocultural effects (for example, cultural identity versus delinquency), and environmental impacts (for example, environmental awareness versus traffic congestion). 


\section{Journal of Travel \& Tourism Marketing}

Table 1 near here

Subsequently, residents will form their attitudes towards tourism based on their perceptions of the economic, sociocultural and environmental impacts of tourism in host communities. The theoretical framework most referenced in past research to explain this link between resident perceptions and attitudes is the Social Exchange Theory (Dyer, Gursoy, Sharma \& Carter, 2007; Gursoy \& Kendall, 2006; Látková \& Vogt, 2012; Vargas et al., 2015). According to this theory, tourists and residents engage in social exchange with the aim of achieving satisfactory outcomes (Sharpley, 2008). Overall, if residents perceive that the positive impacts of tourism in terms of economic, sociocultural and environmental benefits are greater than the costs or negative impacts, then they will have a positive attitude towards tourism development in their communities (Sharpley, 2014). Based on this theory, numerous studies provide empirical evidence of the influence of resident perceptions of tourism's impacts on their attitudes towards tourism or their attitudinal support -for example, Dyer et al. (2007), Nunkoo and Gursoy (2012), Vargas et al. (2015), Wang and Xu (2015), Yoon, Gursoy \& Chen (2001)-.

According to the mentioned theory, and the evidence available in past research, we establish a link between resident perceptions of tourism's impacts and attitudes towards tourism. Most studies -for example, Nunkoo and Gursoy (2012), Vargas et al. (2015) and Nunkoo and So (2016) - establish only two types of effects - i.e. the effects of positive and negative impacts on resident attitudes-. In contrast, our study separately examines the six categories of tourism's impacts -i.e. economic, sociocultural and environmental impacts, both positive and negative- with the aim of exploring their 
differential effects on attitudes, thus reinforcing the explanatory ability of our model. In this sense, it is widely established that resident perceptions on tourism's impacts vary depending on the type of tourism or the stage of tourism development of each host community (Upchurch \& Teivane, 2000; Sheldon \& Abenoja, 2001; Bestard \& Nadal, 2007; Vargas et al., 2009). Consequently, we consider necessary to develop a model that disaggregates the tourism's impacts and is able to explain in detail, in the context of any host community, a complex reality like resident perceptions and attitudes. In addition, this approach is in line with some previous studies in psychology -for example, Caccioppo and Bertson (1994) and Hubbert and Whittington (2003)-, which methodologically question the combination of distinct perceived variables into summary dimensions. Thus, we establish the following hypotheses:

H1. The residents' perceptions of the positive economic impacts of tourism positively influence their attitudes towards tourism development in their communities.

H2. The residents' perceptions of the negative economic impacts of tourism negatively influence their attitudes towards tourism development in their communities.

H3. The residents' perceptions of the positive sociocultural impacts of tourism positively influence their attitudes towards tourism development in their communities.

H4. The residents' perceptions of the negative sociocultural impacts of tourism negatively influence their attitudes towards tourism development in their communities.

H5. The residents' perceptions of the positive environmental impacts of tourism positively influence their attitudes towards tourism development in their communities.

H6. The residents' perceptions of the negative environmental impacts of tourism negatively influence their attitudes towards tourism development in their communities. 


\subsection{Residents' perceptions and attitudes towards tourists}

Although the Social Exchange Theory has been widely used for understanding responses given by residents to tourism phenomena in host communities, Andereck, Valentine, Knopf \& Vogt (2005) consider that the above-mentioned framework may provide an incomplete approach to resident attitudes. In this sense, Woosnam et al. (2009) highlight that this theory examines resident attitudes based merely on a costbenefit perspective or, in other words, in terms of a trade-off between the favourable impacts and negative impacts perceived by residents (Zhang et al., 2006). In addition, some studies using this theory have found mixed results, with no significant relationships between resident perceptions and attitudes (McGehee \& Andereck 2004; Andereck et al., 2005).

This fact has leaded to an alternative approach to resident attitudes that is focused on the interactions between local people and tourists, considered as the essence of tourism (Sharpley, 2014; Yu \& Lee, 2014), in a more emotional and individual sense. In the late 1990s, Lindberg and Johnson (1997) already included residents' pleasure related to the interaction with tourists in their attitudinal model, while Teye, Sönmez \& Sirakaya (2002) found a relationship between the residents' feelings derived of the interaction with tourists and their attitudes. More recently, Woosnam et al. (2009) built the Emotional Solidarity Framework with the purpose of incorporating the feelings towards tourists in the study of resident attitudes. Particularly, emotional solidarity is defined as the affective connection a person has with another individual based on the emotional closeness and grade of contact (Hammarstrom, 2005). In the context of tourism, Woosnam et al. (2009) highlight that residents will experience an emotional solidarity with tourists based on interactions and shared beliefs. Later, empirical research 


\section{Journal of Travel \& Tourism Marketing}

conducted by Woosnam (2012) found a positive relationship between emotional solidarity and attitudinal support for tourism, thus validating this theoretical approach.

Thus, despite the fact that most studies -for example, Stylidis, Biran, Sit \& Szivas (2014), Vargas et al. (2015), Wang and Xu (2015) and Almeida et al. (2016)- have focused on the residents' attitudes towards tourism (cognitive in nature), we consider necessary to also examine the attitudes towards tourists (affective in nature). By taking as a reference the concept of "affective attitudes towards tourists" proposed by Palmer et al. (2013), our study aims to enrich the literature by establishing a link between resident perceptions of the tourism's impacts and their feelings or attitudes towards the tourists. Our statements are based on early studies that use the Social Representations Theory to explain how those perceptions are formed. According to Moscovici (1988), social representations are the mechanisms that individuals use to understand the events and objects around them. In tourism, Zhang et al. (2006) use this theory and establish that residents perceive the tourism's impacts through the social representations of the tourism industry in their communities. In turn, representations are developed among residents based on the information published in the media and other external sources, but also on their direct experiences with tourists (Fredline \& Faulkner 2000).

In this context, we consider that resident-tourist interactions in host communities are a key factor in the formation of resident perceptions and attitudes. Particularly, the evaluations of those interactions made by residents will contribute to the formation of their perceptions about the different tourism's impacts in their communities. In addition, following the traditional "perceptions-attitudes" sequence, we postulate that a positive perception of tourism's impacts by residents, which is based to a certain extent on a favourable evaluation of their interactions with tourists, will lead to a positive attitude 


\section{Journal of Travel \& Tourism Marketing}

towards tourists visiting their communities. Thus, we establish the following hypotheses for each category of tourism's impacts considered in this study:

H7. The residents' perceptions of the positive economic impacts of tourism positively influence their attitudes towards tourists in their communities.

H8. The residents' perceptions of the negative economic impacts of tourism negatively influence their attitudes towards tourists in their communities.

H9. The residents' perceptions of the positive sociocultural impacts of tourism positively influence their attitudes towards tourists in their communities.

H10. The residents' perceptions of the negative sociocultural impacts of tourism negatively influence their attitudes towards tourists in their communities.

H11. The residents' perceptions of the positive environmental impacts of tourism positively influence their attitudes towards tourists in their communities.

H12. The residents' perceptions of the negative environmental impacts of tourism negatively influence their attitudes towards tourists in their communities.

\subsection{Residents' attitudes and behavioural support for tourism}

According to Sharpley (2014), one of the main limitations of past research on residents is that the influence of perceptions and attitudes on subsequent responses or behaviours has been rarely examined. To explain this link, it is fitting to use the theory of reasoned action (TRA) and the theory of planned behaviour (TPB) as references. According to these theories (Ajzen, 1985; Ajzen \& Fishbei, 1980), people's behaviour is a function mainly of their attitudes, which are defined by Eagly and Chaiken (1993) as psychological tendencies expressed by evaluating an 'object' (in the context under investigation, the object would be the host community). These theoretical approaches have been successfully used to predict a wide variety of behaviours based on individual 
attitudes, among them the pro-tourism behaviours (Lepp, 2007). Nunkoo and Ramkinssoon (2010) use TPB to theoretically develop a model linking impacts, attitudes and support for tourism. These authors postulate that if residents have positive attitudes towards tourism, then they will engage in behaviours supporting the tourism activity in their communities.

Some key behaviours in this field would include the recommendation to other people of the host communities, i.e. advocacy behaviour (Palmer et al. 2013), as well as participation in tourism activities in their communities, i.e. self-consumption (O’Shaughnessy \& O'Shaughnessy, 2003). According to Andreck and Vogt (2000) and Andriotis (2005), residents' attitudes would determine the extent to which the local communities will engage or not in these behaviours that offer support for tourism. Palmer et al. (2013) in particular provided some empirical evidence of a positive relationship between the residents' attitudes towards tourists and their propensity to engage in advocacy to support inward tourism. In line with this, our study postulates that a positive attitude towards tourism and tourists will lead to a more positive behaviour supporting tourism in host communities. Therefore, our purpose is to make advancements in the academic literature by introducing the variable of behavioural support and postulating that:

H13. The more positive the residents' attitudes towards tourism, the more positive their behaviour supporting tourism in host communities.

H14. The more positive the residents' attitudes towards tourists, the more positive their behaviour supporting tourism in host communities.

Figure 1 near here

10

URL: http://mc.manuscriptcentral.com/ Email: kaye.chon@polyu.edu.hk 


\section{Journal of Travel \& Tourism Marketing}

\section{Methodology}

To test the previous hypotheses, empirical research was developed in the region of Cantabria, which is located in the north of Spain. This country is the third destination in the world in terms of international tourists incoming (UNWTO, 2017). In addition, Spain was ranked as the most competitive destination worldwide in 2016 (World Economic Forum, 2017), thus being a good benchmark for collecting empirical data on resident perceptions and attitudes in tourism. It is necessary to indicate that, despite the fact that Spain is internationally recognized for its sun and beach tourism, this activity sector is very heterogeneous depending on each specific region. In particular, while sun and beach tourism is predominant in the Mediterranean Coast and the Spanish islands, northern and interior Spain shows a more heterogeneous tourism offer, with a great importance of natural and cultural heritage. Specifically, taking as a reference the extrinsic variables influencing on resident perceptions, as established by Sharpley (2014), the tourism in the region of Cantabria can be defined as a non-mass and seasonal activity, which is mainly based on the natural resources and cultural heritage of the place. Therefore, host community under investigation is reasonably free of bias caused for an intensive development of sun and beach resorts, with high potential impact in environmental and sociocultural terms. In addition, visitors are mainly from other Spanish regions, and international tourists only represent a $15-20 \%$ of the visitors. In this sense, a non-intensive arrival of foreign tourists also reduces the negative potential bias on the formation of perceptions and attitudes among residents.

The target population of empirical research consisted of residents above 18 years old. In particular, data was collected using a personal questionnaire that included the following: 1) the residents' perceptions of the positive and negative impacts usually related to the 


\section{Journal of Travel \& Tourism Marketing}

tourism activity; 2) the residents' attitudes towards tourism and tourists; 3) the residents' behavioural support for tourism in host communities; and 4) the sociodemographic characteristics of respondents. The variables of the theoretical model were all measured using multi-attribute instruments adapted from previous works in order to assure their content validity -see Appendix-. In particular, residents' perceptions of the positive and negative impacts of tourism were measured taking as an initial reference frame the set of impacts considered in several recent empirical works -Nunko and Gursoy (2012); Prayag, Hosany, Nunkoo, Alders, Igan, \& Attalla (2013), Garau et al. (2014); Sinclair et al. (2015); Vargas et al. (2015) and Wang and Xu (2015)-. We checked the list of impacts to avoid duplications and, subsequently, three main impacts for each category were selected (i.e. those that better fit the characteristics of the host community under investigation). For its part, attitudes towards tourism were measured with an instrument adapted from the study of Wang et al. (2006), while attitudes towards tourists were captured based on the instruments developed by Teye et al. (2002) and Palmer et al. (2013). Finally, behavioural support for tourism was measured taking as a reference the concept of residents' participation in tourism, as established by Palmer et al. (2013). It is necessary to indicate that all the items were measured with a ten-point Likert scale in order to ensure the variability of data.

For its part, the sampling strategy consisted of two stages and methods; in the first phase, we used a quota method to build the profile of respondents according to the characteristics of the population under investigation. In particular, we used the statistics provided by ICANE -i.e. an observatory of the population in the region of Cantabria- to determine the distribution (or percentages) of residents by gender and age. In a second stage, we used a convenience method to define the geographical areas for data collection. Particularly, we selected the main areas in the region of Cantabria according 
to the statistics of arrival of tourists provided from ICANE; for example, the municipality of Santander or the Area of Torrelavega were selected for data collection. With this information, the interviewers were distributed in the different geographical areas and were trained to administer the questionnaire without causing bias in the responses, obtaining a valid sample of 619 residents (Table 2 provides the sociodemographic characteristics of the respondents). In relation to the gender and age of respondents, it is important to indicate that the survey sample is close to the target population, thus achieving an adequate level of typological representativeness of our sample.

Table 2 near here

\section{Results}

A SEM approach was used in order to test our research model. Firstly, the reliability and validity of the measurement scales were checked by means of a confirmatory factor analysis using EQS 6.1 software (see Table 3). The fit criteria indicate the extent to which the factorial model fits the data. In particular, three types of criteria are relevant to assess the model fit for the data: measures of absolute fit (BBNNFI is very near the recommended valued of 0.90 , and RMSEA is below 0.08 ), measures of incremental fit

(IFI and CFI are above the recommended value of 0.90) and measures of parsimonious fit (normed $\chi^{2}$ is below 3.0).

The reliability of our measurement scales was evaluated using the Cronbach's Alpha, compound reliability, and AVE coefficients (Bagozzi and Yi 1988) (Table 3). The values of Cronbach's Alpha and compound reliability are, in almost every case, clearly 
above the required minimum values of 0.7 (Hair et al. 2010). For its part, AVE coefficients are above of the recommended value of 0.5 (Hair et al. 2010), except in the cases of "Behavioural support for tourism", "Attitude towards tourism" and "Perception of positive sociocultural impacts". However, it is necessary to indicate that: 1) in the last two cases the AVE coefficients are very close to 0.5 ; and 2) "Behavioural support for tourism" is a construct scarcely studied in the literature and whose scale may require refinement in further research, even though the values obtained for the Cronbach's alpha and Composite Reliability are reasonably good. Accordingly, we consider that the results obtained for supporting the reliability of our scales are acceptable.

The convergent validity of our scales was also confirmed (see Table 3), since all items are significant to a confidence level of $95 \%$ and their standardized lambda coefficients are higher than 0.5 (Steenkamp and Van Trijp 1991). For its part, the discriminant validity of the scales was tested following the procedure proposed by Fornell and Larcker (1981), which requires the comparison of the variance extracted for each pair of constructs (AVE coefficient) with the squared correlation estimated between constructs. Despite the low value of the AVE coefficient for the latent variable "Behavioural support for tourism", the results summarized in table 4 show that there are not discriminant validity problems, as the AVE is higher than the squared correlation between each pair of latent variables. This, together with the reasonably good indicators obtained for convergent validity -i.e. Lambda coefficients-, and reliability -i.e. Cronbach's alpha and Composite Reliability-, support the general psychometric properties of the latent factor "Behavioural support for tourism". Accordingly, empirical results support the psychometric properties of the scales used in this research.

Table 3 near here 


\section{Journal of Travel \& Tourism Marketing}

Table 4 near here

Next, the structural model was estimated to test our research hypotheses. The analysis was run using a robust maximum-likelihood estimation procedure, which avoids the problems related to non-normality of data by providing the outputs 'robust chi-square statistic' and 'robust standard errors'. These outputs have been corrected for nonnormality (Byrne, 1994) and, consequently, guarantee the validity of the model estimation. The results obtained in the first estimation of the model show that six research hypotheses are not significant. In particular, the residents' attitudes towards tourism are not significantly affected by their perceptions of the negative economic impacts or by their perceptions of positive/negative environmental impacts (H4, H5 and H6 are rejected). In addition, the residents' attitudes towards tourists are not significantly affected by their perceptions of negative economic and sociocultural impacts or by their perceptions of positive environmental impacts (H8, H10 and H11 are rejected).

Following the procedure proposed by Hair et al. (2010), we proceeded to the respecification of the model by eliminating the causal relationships not supported by empirical data. Once the model was re-specified, the goodness-of-fit indexes obtained were within the recommended values (Table 5). Specifically, our results indicate that the residents' attitudes towards tourism are positively influenced by their perceptions of the positive economic and sociocultural impacts and negatively influenced by their perceptions of negative sociocultural impacts (H1, H3 and $\mathrm{H} 4$ are confirmed). In addition, our results confirm that the residents' attitudes towards tourists are positively influenced by their perceptions of the positive economic and sociocultural impacts and 
negatively influenced by their perceptions of negative environmental impacts (H7, H9 and $\mathrm{H} 12$ are confirmed). In addition, it is important to note that residents' behaviours supporting tourism in their communities are influenced in a similar way by their attitudes towards tourism and their attitudes towards tourists (H13 and H14 are confirmed). Finally, is necessary to indicate that the $\mathrm{R}^{2}$ statistics for each dependent variable were higher than 0.4 (or very close to this recommended value), thus reflecting that a significant percentage of variation in the dependent variables was explained by the independent variables (see Table 5).

Table 5 near here

\section{Conclusions}

Resident perceptions of tourism's impacts, and their influence on attitudes towards tourism in host communities, have received a lot of attention in previous research. However, several recent studies demand more effort to examine in greater depth this relevant topic for academicians and practitioners. In this sense, our study represents a new step in the study of tourism phenomenon from the resident point of view by taking a different and more comprehensive approach. On the one hand, our study generate new knowledge about the chain of effects from the perceptions of tourism's impacts to attitudes in the context of communities hosting non-mass tourism (in contrast to the most studied communities that host a mass tourism, mainly based on sun and beach).

On the other hand, our study examines not only the relationships between resident perceptions and attitudes, but also the links between resident attitudes and subsequent behaviours. Particularly, our study develops a new model that is based on the 


\section{Journal of Travel \& Tourism Marketing}

'perceptions-attitudes-behaviours' sequence and includes two types of resident attitudes -i.e. attitudes towards tourism and attitudes towards tourists- and the novel concept of behavioural support -i.e. resident behaviours supporting tourism in host communities-.

With regard to the formation of attitudes, our results confirm that the residents' perceptions of the positive economic impacts of tourism is the main variable determining their attitudes towards tourism development in their communities. This finding is in line with Vargas et al. (2015), who establish that the perceptions of these specific impacts have been identified to be the most influential factor on resident attitudes formation. In addition, according to the Social Exchange Theory, residents aim to obtain satisfactory outcomes with tourism developed in their communities. Thus, in a context of economic crisis that many places are suffering nowadays, it is logical to think that the perceptions of the economic opportunities that tourism generate in host communities (for example, job opportunities and new businesses) are the most critical factor for residents in the formation of their attitudes towards tourism.

Furthermore, another important contribution of this study is related to the formation of other type of resident attitudes, those linked to the tourists, which have received little academic attention in literature. Unlike the study of Palmer et al. (2013), which defines these attitudes as an antecedent to advocacy behaviour, our paper also examines how resident attitudes towards tourists are influenced by their perceptions of tourism's impacts. In this context, it has been empirically demonstrated that the perception of the positive sociocultural impacts of tourism is the most important variable influencing attitude towards tourists in host communities. This finding is coherent with the development of the Social Representations Theory in tourism. More concretely, it is reasonable to believe that positive sociocultural impacts are the category of tourism's impacts more likely to be conditioned by the interactions between residents and tourists 
in host communities (a key element in the formation of social representations in tourism). Therefore, the perceptions of these specific impacts would represent a key factor in the formation of attitudes towards tourists. In addition, these attitudes are also affected by the perceptions of both the positive economic impacts and the negative environmental impacts, but to a lesser extent.

In relation to the tourism's impacts that are not found to influence the residents' attitudes (i.e. negative economic impacts and positive environmental impacts), it may be due to two reasons. First, the tourism development model of the region under investigation is not based on a mass tourism model, so the negative economic impacts (usually attributed to conventional tourism) are relatively small and, consequently, residents may not consider them a key element in the formation of their attitudes. Second, one of the main motivations for tourists visiting this Spanish region is the contact with nature, so residents may place some importance on the negative environmental impacts of this type of tourism, but not particularly consider the positive ones when they form their attitudes.

Finally, it is also important to emphasize that our paper represents a significant effort to generate new knowledge about the influence of attitudes on subsequent behaviours or responses of residents. In comparison to some previous studies such as Látková and Vogt (2012), Nunkoo and Ramkissoon (2011), Nunkoo and So (2016), Rasoolimanesh et al. (2017) and Wang and Pfister (2008), our study goes further in analysing these responses and examines the concept of behavioural support for tourism, which represents a more reliable variable to measure the true commitment with the tourism than the attitudinal support. Particularly, in line with previous studies that have demonstrated an 'attitude-behaviour' link based on the Theory of Reasoned Action or the Theory of Planned Behaviour, our results confirm that resident attitudes positively 
influence behaviours supporting tourism in host communities. In particular, resident behaviours in terms of participation in tourism activities in their communities and recommendation of these places to other people (i.e. behavioural support) are affected, in a similar way, by their attitudes towards tourism and their attitudes towards tourists.

\subsection{Managerial implications}

In a review of previous research, Sharpley (2014) emphasizes the significance of examining not only the perceptions-attitudes relationship, but also the responses or actions of residents from a management perspective. In this sense, we recommend destination managers to develop a variety of social responsibility activities in order to enhance the quality of the relationship with residents and, therefore, reinforce their attitudes and behavioural support for tourism. These activities, which require a close coordination among the public sector and the private sector (Su et al., 2016), should be mainly focused on different campaigns that raise awareness of the positive impacts of tourism among local residents. Specifically, destination managers may use both conventional communication (for example, advertising or public relations) to target older people, as well as communication 2.0 (for example, social networks or photosharing websites) to target younger people, in order to achieve this goal. In addition, destination social responsibility should pay attention to other issues such as enhance the physical and cultural well-being of residents, increase the participation of the local community in decision-making processes, or comply with the different kinds of regulations.

Although our findings indicate that those positive tourism impacts are the most influential factors in the formation of residents' attitudes, destination managers should not forget to minimize the negative impacts typically perceived by residents related to tourism activity. More concretely, managers should pay special attention to the negative 
sociocultural and environmental impacts in their host communities. With this in mind, the objective should be to involve residents in different activities, such as workshops or meetings in a natural environment, for the purposes of eliminating certain stereotypes surrounding the cultural and environmental damage of tourism activity and/or explaining the measures developed by the communities to reduce undesirable tourist behaviours.

\subsection{Limitations and further research}

Despite the rigorous methodology used in empirical research, this study has several limitations that should be managed in future research. First, the fact that this research focuses on a specific Spanish region could be a constraint in the generalization of our results. In this sense, it would be interesting to replicate empirical research in other communities with different types of tourism or different state of development. Specifically, host communities promoting new products alternative to sun and beach tourism may be interested in examining how the different types of tourism influence the perceptions and attitudes of residents. Thus, policy makers can develop their tourism development strategies in a more efficient way. Second, the analysis of the 'perceptionsattitudes-behaviours' sequence has been conducted for all residents considered in empirical research. It would be very interesting to examine how the model works depending on different variables such as the personal values or socio-demographic characteristics of residents. Finally, some of the measurement scales show values below 0.5 for the AVE coefficient, which might raise some doubts about their reliability. However, the values obtained for Cronbach's Alpha and compound reliability support inner reliability of all the scales. This problem is slightly bigger with regard to the dependent variable (i.e. behavioural support for tourism), whose operationalization 
should be refined by revising the proposed items and adding other behaviours such as volunteering in tourism activities or buying local products in their communities.

\section{References}

Ajzen, I., \& M. Fishbein. (1980). Understanding attitudes and predicting social behavior. Englewood Cliffs, NJ: Prentice-Hall.

Ajzen, I. (1985). From intentions to actions. In J. Kuhl \& J. Bechman (Eds.), Action control from cognition to behavior (pp. 11-39). New York: Springer Verlag.

Almeida, F., A. Balbuena, \& R. Cortés (2015). Resident's attitudes towards the impacts of tourism. Tourism Management Perspectives, 13, 33-40.

Almeida, F., M. Peláez, A. Balbuena, \& R. Cortés (2016). Residents' perceptions of tourism development in Benalmádena (Spain). Tourism Management, 54, 259-274.

Andereck, K. L., \& C. A. Vogt (2000). The relationship between residents' attitudes towards tourism and tourism development options. Journal of Travel Research, 39 (1), $27-36$

Andereck, K. L., K.M. Valentine, R. C. Knopf, \& C. A. Vogt (2005). Residents' perceptions of community tourism impacts. Annals of Tourism Research, 32 (4), 10561076.

Andriotis, K. L. (2005). Community groups' perceptions of and preferences for tourism development. Evidence from Crete. Journal of Hospitality and Tourism Research, 29 (1), 67-90.

Ap, J. (1992). Residents' perceptions on tourism impacts. Annals of Tourism Research, 19, 665-69. 
Bestard, B., \& R. Nada (2007). Attitudes toward tourism and tourism congestion. Région et Développment, 25, 193-207.

Bianchi, C. (2015). Solo holiday travellers: Motivators and drivers of satisfaction and dissatisfaction. International Journal of Tourism Research, 18 (2), 197-208.

Byrne, B. M. (1994). Structural equation modeling with EQS and EQS/Windows. Thousand Oaks, CA: Sage Publications.

Cacioppo, J. T., \& G. G. Bertson (1994). Relationship between attitudes and evaluative space: A critical review, with emphasis on the separability of positive and negative substrates. Psychological Bulletin, 115 (3), 401-423.

Diedrich, A., \& E. García (2009). Local perceptions of tourism as indicators of destination decline. Tourism Management, 30 (4), 512-521

Dyer, P., D. Gursoy, B. Sharma, \& J. Carter (2007). Structural modelling of resident perceptions of tourism and associated development on the sunshine coast, Australia. Tourism Management, 28 (2), 409-422.

Eagly, A., \& S. Chaiken (1993). The psychology of attitudes. Fort Woth, TX: Harcout Brace Jovanovich.

Easterling, D.S. (2004). The residents' perspective in tourism research. Journal of Travel \& Tourism Marketing, 17 (4), 45-62.

Fornell, C., \& D. F. Larcker (1981). Evaluating structural equation models with unobservable variables and measurement error. Journal of Marketing Research, 18 (1), $39-50$.

Fredline, E., \& B. Faulkner (2000). Host community reactions: A cluster analysis. Annals of Tourism Research, 27 (3), 763-784. 
Garau, J.B., R. Díaz, \& D. Gutiérrez (2014). Residents’ perceptions of tourism impacts on island destinations: A comparative analysis. International Journal of Tourism Research, 16, 578-585.

Gu, H., \& C. Ryan (2008). Place attachment, identity and community impacts of tourism — The case of a Beijing hutong. Tourism Management, 29 (4), 637-647.

Gursoy, D., \& K.W. Kendall (2006). Hosting mega events: Modelling locals'support. Annals of Tourism Research, 33 (3), 603-623.

Hammarstrom, G. (2005). The construct of intergenerational solidarity in a lineage perspective: A discussion on underlying theoretical assumptions. Journal of Aging Studies, 19 (1), 33-51.

Herrero, A., H. San Martín, M.M. García-de los Salmones, \& J. Collado (2016). Examining the hierarchy of destination brands and the chain of effects between brand equity dimensions. Journal of Destination Marketing \& Management. Advance online publication.

Hubbert, F. A., \& J. E. Whittington (2003). Evidence for the independence of positive and negative well-being: Implications for quality of life assessment. British Journal of Health Psychology, 8, 107-122.

Jurowski, C., \& D. Gursoy (2004). Distance effects on residents' attitudes toward tourism. Annals of Tourism Research, 31 (2), 296-312.

Jurowski, C., M. Uysal, \& D.R.Williams (1997). A theoretical analysis of host community resident reactions to tourism. Journal of Travel Research, 34 (2), 3-11.

Key, C., \& V. Pillai (2006). Community Participation and Tourism Attitudes in Belize. Interamerican Journal of Environment and Tourism, 2 (2), 8-15. 
Kuvan, Y., \& P. Akan, P. (2005). Residents' attitudes toward general and forest-related impacts of tourism: The case of Belek, Antalya. Tourism Management, 26 (5), 691-706.

Kwon J., \& C.A. Vogt (2010). Identifying the role of cognitive, affective, and behavioural components in understanding residents' attitudes toward place marketing. Journal of Travel Research, 49 (4), 423-435.

Látková, P., \& C.A. Vogt 2012. “Residents' attitudes toward existing and future tourism development in rural communities”. Journal of Travel Research 51 (1), 50-67.

Lepp, A. (2007). Residents' attitudes towards tourism in Bigodi village, Uganda. Tourism Management, 28 (3), 876-885.

Lindberg, K., \& R. L. Johnson 1997. "Modeling resident attitudes toward tourism”. Annals of Tourism Research 24 (2), 402-424.

Litvin, S. W., R.E. Goldsmith, \& B. Pan (2008). Electronic word-of-mouth in hospitality and tourism management. Tourism Management, 29 (3), 458-468.

Moscovici, S. (1988). Notes toward a description of social representations. European Journal of Social Psychology, 18, 211-250.

Nunkoo, R., \& D. Gursoy (2012). Residents' support for tourism an identity perspective. Annals of Tourism Research, 39 (1), 243-268.

Nunkoo, R., \& H. Ramkissoon (2010). Gendered theory of planned behavior and residents' support for tourism. Current Issues in Tourism, 13 (6), 525-540.

Nunkoo, R., \& K.K.F. So (2016). Residents' support for tourism: Testing alternative structural models. Journal of Travel Research, 55 (7), 847-861.

Oppermann, M. (1995). Holidays on the farm: A case study of German hosts and guests. Journal of Travel Research, 34 (1), 63-67. 
O’shaughnessy, J., \& N.J. O’shaughnessy (2003). The marketing power of emotion. Oxford: Oxford University Press.

Prayag, G., S. Hosany, R. Nunkoo, T. Alders, M. Igan, \& A. Attalla (2013). London residents' support for the 2012 Olympic Games: The mediating effect of overall attitude. Tourism Management, 36, 629-640.

Palmer, A., N. Koenig-Lewis \& L.E. Medi Jones (2013). The effects of residents' social identity and involvement on their advocacy of incoming tourism. Tourism Management $38,142-151$.

Rasoolimanesh, S.F., J.L. Roldán, M. Jaafar, \& T. Ramayah (2016). Factors influencing residents' perceptions toward tourism development: Differences across rural and urban world heritage sites. Journal of Travel Research, Empirical Research Articles, 1-16.

Ribeiro, M. A., P. Pinto; J. A. Silva, \& K. M. Woosnam (2017). Residents' attitudes and the adoption of pro-tourism behaviours: The case of developing island countries. Tourism Management, 61, 523-537.

Sharpley, R. (2008). Tourism, tourists and society (4th ed.). Huntingdon: Elm Publications.

Sharpley, R. (2014). Host perceptions of tourism: A review of the research. Tourism Management 42, 37-49.

Sheldon, P., \& T. Abenjona, (2001). Resident attitudes in a mature destination: The case of Waikiki. Tourism Management, 22 (5), 435-443.

Sinclair, G., D. Gursoy, \& M. Vieregge (2015). Residents' perceptions toward tourism development: A factor-cluster approach. Journal of Destination Marketing \& Management, 4 (1), 36-45. 
Stylidis, D., A. Biran, J. Sit, \& E.M. Szivas (2014). "Residents' support for tourism development: The role of residents' place image and perceived tourism impacts". Tourism Management, 45, 260-274.

Su, L., L. Wang, R. Law, X. Chen, \& D. Fong (2016). “Influences of destination social responsibility on the relationship quality with residents and destination economic performance”. Journal of Travel \& Tourism Marketing (Advance online publication). Teye, V., S.F. Sönmez, \& E. Sirakaya (2002). Residents’ attitudes toward tourism development. Annals of Tourism Research, 29 (3), 668-688.

UNWTO (2017): UNWTO Tourism Highlights, 2016 Edition. Available on line: www.e-unwto.org/doi/book/10.18111/9789284418145.

Upchurch, R., \& U. Teivane (2000). Resident perceptions of tourism development in Riga, Latvia. Tourism Management, 21 (5), 499-507.

Vargas, A., P. Oom, J. Da Costa, \& J. Albiño (2015). Residents' attitude and level of destination development: An international comparison. Tourism Management, 48, 199210.

Vargas, A., M. Plaza, \& N. Porra (2009). Understanding residents' attitudes toward the development of industrial tourism in a former mining. Journal of Travel Research, 47 (3), 373-387.

Wang, S., \& H. Xu. (2015). Influence of place-based senses of distinctiveness, continuity, self-esteem and self-efficacy on residents' attitudes toward tourism. Tourism Management, 47, 241-250.

Wang, Y., \& R.E. Pfister (2008). Residents' attitudes toward tourism and perceived personal benefits in a rural community. Journal of Travel Research, 47, 84-93. 


\author{
Wang, Y., R. E. Pfister, \& D. B. Morais (2006). Residents' attitudes toward tourism \\ development: A case study of Washington, NC. Proceedings of the 2006 Northeastern \\ Recreation Research Symposium, 411-418.
}

Woosnam, K. M. (2012). Using emotional solidarity to explain residents' attitudes about tourism and tourism development. Journal of Travel Research 51 (3), 315-327.

Woosnam, K. M., \& W. C. Norman (2010). Measuring residents' emotional solidarity with tourists: Scale development of Durkheim's theoretical constructs. Journal of Travel Research, 49 (3), 365-380.

Woosnam, K. M., W. C. Norman, \& T. Ying (2009). Exploring the theoretical framework of emotional solidarity between residents and tourists. Journal of Travel Research, 48 (2), 245-258.

World Economic Forum (2017): The Travel \& Tourism Competitiveness Report 2017. World Economic Forum, Geneva

Yoo, J., Y. Zhou, T. Lu, \& T. Kim. (2014). The moderating effects of resident characteristics on perceived gaming impacts and gaming industry support: The case of Macao. Journal of Travel \& Tourism Marketing, 31 (2), 229-250.

Yoon, Y., D. Gursoy, \& J.S. Chen (2001). Validating a tourism development theory with structural equation modelling. Tourism Management, 22 (4), 363-372.

Yu, J., \& T. J. Lee (2014). Impact of tourists' intercultural interactions. Journal of Travel Research, 53 (2), 225-238.

Zhang, J., R. Inbakaran, \& M. Jackson (2006). Understanding community attitudes towards tourism and host-guest interaction in the urban-rural border region. Tourism Geographies: An International Journal of Tourism Space, Place and Environment, 8 (2), 182-204. 


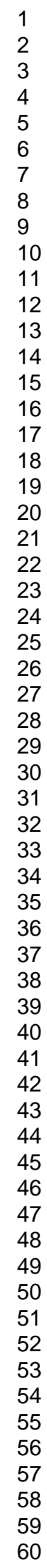


Appendix

\begin{tabular}{|c|c|}
\hline Variable & Items \\
\hline $\begin{array}{l}\text { Perception of } \\
\text { positive economic } \\
\text { impacts }\end{array}$ & $\begin{array}{l}\text { Tourism increases job opportunities in my region } \\
\text { Tourism improves the infrastructure and public services in my region } \\
\text { Tourism contributes to increasing the reputation of my region abroad }\end{array}$ \\
\hline $\begin{array}{l}\text { Perception of } \\
\text { negative economic } \\
\text { impacts }\end{array}$ & $\begin{array}{l}\text { Tourism generates an increase in taxes in my region } \\
\text { Tourism increases the cost of living (prices of products and services) in } \\
\text { my region } \\
\text { Tourism contributes to generating undesirable businesses (prostitution, } \\
\text { etc.) in my region }\end{array}$ \\
\hline $\begin{array}{l}\text { Perception of } \\
\text { positive } \\
\text { sociocultural } \\
\text { impacts }\end{array}$ & $\begin{array}{l}\text { Tourism provides a better understanding of other cultures for the } \\
\text { residents in my region } \\
\text { Tourism increases the pride of belonging to my region } \\
\text { Tourism reinforces cohesion among the residents in my region }\end{array}$ \\
\hline $\begin{array}{l}\text { Perception of } \\
\text { negative } \\
\text { sociocultural } \\
\text { impacts }\end{array}$ & $\begin{array}{l}\text { Tourism causes damage to the cultural heritage of my region } \\
\text { Tourism leads to the collapse of public services offered in my region } \\
\text { Tourism increases theft and vandalism in my region }\end{array}$ \\
\hline $\begin{array}{l}\text { Perception of } \\
\text { positive } \\
\text { environmental } \\
\text { impacts }\end{array}$ & $\begin{array}{l}\text { Tourism is an incentive to conserve natural resources in my region } \\
\text { Tourism leads to greater environmental awareness among the residents } \\
\text { in my region } \\
\text { Tourism facilitates the development of public instruments to control }\end{array}$ \\
\hline
\end{tabular}


Journal of Travel \& Tourism Marketing

\begin{tabular}{|c|c|}
\hline & the environmental impact of tourism activities in my region \\
\hline $\begin{array}{l}\text { Perception of } \\
\text { negative } \\
\text { environmental } \\
\text { impacts }\end{array}$ & $\begin{array}{l}\text { Tourism causes damages to the natural environment in my region } \\
\text { Tourism increases pollution levels in my region } \\
\text { Tourism generates traffic and parking problems in my region }\end{array}$ \\
\hline $\begin{array}{l}\text { Attitude towards } \\
\text { tourism }\end{array}$ & $\begin{array}{l}\text { I believe tourism generates positive benefits to my region } \\
\text { I believe tourism is a good activity for my region } \\
\text { I would like the tourism sector to continue to play a major role in my } \\
\text { region } \\
\text { I believe tourism should be actively encouraged in my region }\end{array}$ \\
\hline $\begin{array}{l}\text { Attitude towards } \\
\text { tourists }\end{array}$ & $\begin{array}{l}\text { For me, interacting with tourists who visit my region is pleasant } \\
\text { For me, interacting with tourists who visit my region is enjoyable } \\
\text { For me, interacting with tourists who visit my region is funny } \\
\text { For me, interacting with tourists who visit my region is positive }\end{array}$ \\
\hline $\begin{array}{l}\text { Behavioural } \\
\text { support for tourism }\end{array}$ & $\begin{array}{l}\text { I like visit tourist sites in my region } \\
\text { I recommend the tourist attractions that exist in my region to other } \\
\text { people } \\
\text { I offer my assistance to tourism events/activities organized in my } \\
\text { region } \\
\text { In the next few years, I will try to choose a tourist site in my region to } \\
\text { spend my holidays }\end{array}$ \\
\hline
\end{tabular}


TABLE 1

\section{Residents' perceptions of tourism impacts}

\begin{tabular}{|c|c|c|}
\hline $\begin{array}{l}\text { Type of } \\
\text { impact }\end{array}$ & Description & Recent studies \\
\hline $\begin{array}{l}\text { Economic } \\
\text { impacts }\end{array}$ & $\begin{array}{l}\text { Positive impacts: generation of employment } \\
\text { opportunities, creation of local businesses } \\
\text { environments, or improvements in public } \\
\text { infrastructure and facilities, among others benefits } \\
\text { that increase living standards. } \\
\text { Negative impacts: rise of the prices of goods and } \\
\text { services (i.e. inflation), disparity in the } \\
\text { distribution of resources, increase of local taxes, } \\
\text { or generation of undesirable businesses, among } \\
\text { others costs. }\end{array}$ & $\begin{array}{l}\text { Fredline and Faulkner } \\
\qquad(2000) \\
\text { Yoon et al. (2001) } \\
\text { Haley et al. (2005) } \\
\text { Kuvan and Akan (2005) } \\
\text { Wang et al. (2006) }\end{array}$ \\
\hline $\begin{array}{l}\text { Sociocultural } \\
\text { impacts }\end{array}$ & $\begin{array}{l}\text { Positive impacts: improvement of cultural } \\
\text { activities and facilities, preservation of cultural } \\
\text { traditions, or rise of pride and cultural identity, } \\
\text { among others benefits. } \\
\text { Negative impacts: damages in the cultural } \\
\text { heritage, collapse in public services, or increase } \\
\text { of the delinquency and vandalism, among others } \\
\text { negative effects. }\end{array}$ & $\begin{array}{l}\text { Dyer et al. (2007) } \\
\text { Gu and Ryan (2008) } \\
\text { Diedrich and García } \\
\text { (2009) } \\
\text { Vargas et al. (2011) } \\
\text { Nunko and Gursoy } \\
\text { (2012) } \\
\text { Prayag et al. (2013) }\end{array}$ \\
\hline $\begin{array}{l}\text { Environmental } \\
\text { impacts }\end{array}$ & $\begin{array}{l}\text { Positive impacts: preservation of natural } \\
\text { resources, or improvement of environmental } \\
\text { awareness in the destination community, among } \\
\text { others positive effects. } \\
\text { Negative impacts: environmental degradation, } \\
\text { increase of pollution levels, or traffic congestion } \\
\text { and parking problems, among others } \\
\text { environmental costs. }\end{array}$ & $\begin{array}{l}\text { Almeida et al. (2015) } \\
\text { Sinclair et al. (2015) } \\
\text { Vargas et al. (2015) } \\
\text { Wang and Xu (2015) }\end{array}$ \\
\hline
\end{tabular}


FIGURE 1

\section{Theoretical model}

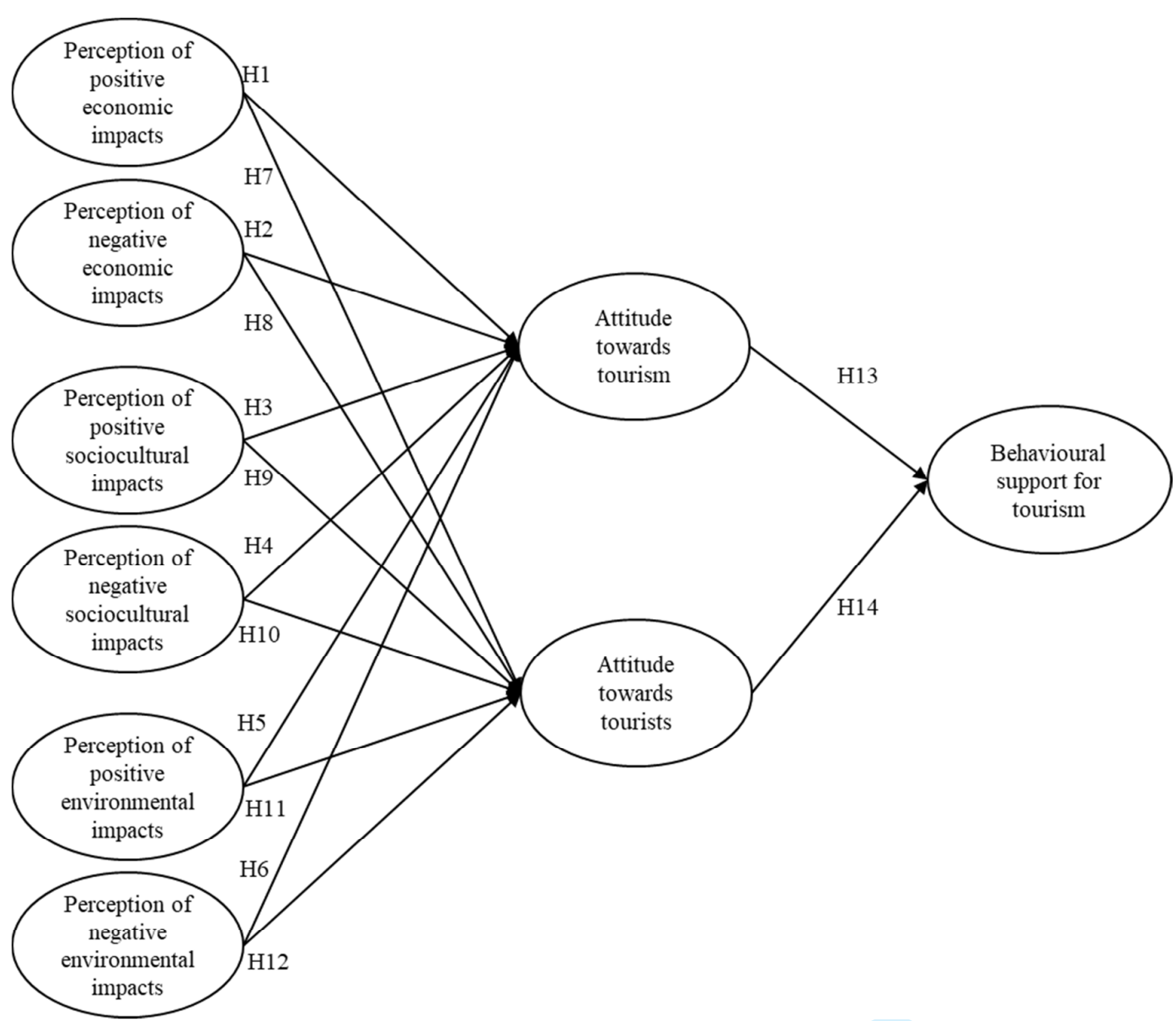

42

43

44

45

46

47

48

49

50

51

52

53

54

55

56

57

58

59

60 
TABLE 2

Profile of respondents

\begin{tabular}{|l|c|l|c|}
\hline Variable & \% & Variable & $\%$ \\
\hline Gender & $48.3(48.0)^{*}$ & $18-34$ years old & \\
Female & $51.7(52.0)^{*}$ & $35-49$ years old & $28.4(23.1)^{*}$ \\
& & $50-64$ years old & $26.5(29.4)^{*}$ \\
& & 65 years old or more & $25.5(24.5)^{*}$ \\
\hline Level of studies & 8.3 & Worker & $19.6(23.0)^{*}$ \\
Without studies & 15.9 & Student & 45.9 \\
Primary studies & 39.1 & House wife & 19.6 \\
Secondary studies & 36.7 & Retired/unemployed & 23.8 \\
University studies & & & \\
\hline
\end{tabular}

* Data of Population Census 2011. 
TABLE 3

Confirmatory factor analysis

\begin{tabular}{|c|c|c|c|c|c|c|c|}
\hline Factor & Var. & $\begin{array}{c}\text { Standard } \\
\text { Coefficient }\end{array}$ & $\mathbf{R}^{2}$ & $\begin{array}{c}\text { Cronbach's } \\
\alpha\end{array}$ & $\begin{array}{l}\text { Composite } \\
\text { Reliability }\end{array}$ & AVE & $\begin{array}{c}\text { Goodness } \\
\text { of fit } \\
\text { indices }\end{array}$ \\
\hline \multirow{4}{*}{$\begin{array}{l}\text { Behavioural } \\
\text { support for } \\
\text { tourism }\end{array}$} & BST1 & 0.703 & 0.494 & \multirow{4}{*}{0.687} & \multirow{4}{*}{0.706} & \multirow{4}{*}{0.379} & \multirow{21}{*}{$\begin{array}{c}\text { Normed } \\
\chi^{2}=2.91 \\
\text { BBNNFI } \\
=0.89 \\
\text { IFI }=0.91 \\
\text { CFI }= \\
0.91 \\
\text { RMSEA } \\
=0.05\end{array}$} \\
\hline & BST2 & 0.661 & 0.437 & & & & \\
\hline & BST3 & 0.517 & 0.267 & & & & \\
\hline & BST4 & 0.562 & 0.316 & & & & \\
\hline \multirow{4}{*}{$\begin{array}{l}\text { Attitude } \\
\text { towards } \\
\text { tourism }\end{array}$} & ATM1 & 0.685 & 0.470 & \multirow{4}{*}{0.822} & \multirow{4}{*}{0.790} & \multirow{4}{*}{0.488} & \\
\hline & ATM2 & 0.809 & 0.655 & & & & \\
\hline & ATM3 & 0.632 & 0.399 & & & & \\
\hline & ATM4 & 0.654 & 0.428 & & & & \\
\hline \multirow{4}{*}{$\begin{array}{l}\text { Attitude } \\
\text { towards } \\
\text { tourists }\end{array}$} & ATS1 & 0.801 & 0.642 & \multirow{4}{*}{0.925} & \multirow{4}{*}{0.927} & \multirow{4}{*}{0.760} & \\
\hline & ATS2 & 0.934 & 0.873 & & & & \\
\hline & ATS3 & 0.890 & 0.792 & & & & \\
\hline & ATS4 & 0.856 & 0.732 & & & & \\
\hline \multirow{3}{*}{$\begin{array}{l}\text { Perception of } \\
\text { positive } \\
\text { economic } \\
\text { impacts }\end{array}$} & PEI1 & 0.740 & 0.548 & \multirow{3}{*}{0.829} & \multirow{3}{*}{0.830} & \multirow{3}{*}{0.619} & \\
\hline & PEI2 & 0.786 & 0.617 & & & & \\
\hline & PEI3 & 0.832 & 0.693 & & & & \\
\hline Perception of & NEI1 & 0.806 & 0.650 & \multirow{3}{*}{0.774} & \multirow{3}{*}{0.788} & \multirow{3}{*}{0.558} & \\
\hline $\begin{array}{l}\text { negative } \\
\text { economic }\end{array}$ & NEI2 & 0.813 & 0.660 & & & & \\
\hline impacts & NEI3 & 0.602 & 0.362 & & & & \\
\hline \multirow{3}{*}{$\begin{array}{l}\text { Perception of } \\
\text { positive } \\
\text { sociocultural } \\
\text { impacts }\end{array}$} & PSCI1 & 0.567 & 0.321 & \multirow{3}{*}{0.709} & \multirow{3}{*}{0.732} & \multirow{3}{*}{0.482} & \\
\hline & PSCI2 & 0.809 & 0.654 & & & & \\
\hline & PSCI3 & 0.686 & 0.471 & & & & \\
\hline
\end{tabular}




\begin{tabular}{|c|c|c|c|c|c|c|}
\hline \multirow{3}{*}{$\begin{array}{l}\text { Perception of } \\
\text { negative } \\
\text { sociocultural } \\
\text { impacts }\end{array}$} & NSCI1 & 0.767 & 0.589 & \multirow{3}{*}{0.766} & \multirow{3}{*}{0.767} & \multirow{3}{*}{0.525} \\
\hline & NSCI2 & 0.760 & 0.578 & & & \\
\hline & NSCI3 & 0.639 & 0.408 & & & \\
\hline \multirow{3}{*}{$\begin{array}{l}\text { Perception of } \\
\text { positive } \\
\text { environmental } \\
\text { impacts }\end{array}$} & PEI1 & 0.808 & 0.653 & \multirow{3}{*}{0.808} & \multirow{3}{*}{0.814} & \multirow{3}{*}{0.595} \\
\hline & PEI2 & 0.828 & 0.685 & & & \\
\hline & PEI3 & 0.669 & 0.448 & & & \\
\hline \multirow{3}{*}{$\begin{array}{l}\text { Perception of } \\
\text { negative } \\
\text { environmental } \\
\text { impacts }\end{array}$} & NEI1 & 0.756 & 0.572 & \multirow{3}{*}{0.800} & \multirow{3}{*}{0.814} & \multirow{3}{*}{0.598} \\
\hline & NEI2 & 0.906 & 0.820 & & & \\
\hline & NEI3 & 0.633 & 0.400 & & & \\
\hline
\end{tabular}


TABLE 4

Discriminant validity tests

\begin{tabular}{|c|c|c|c|c|c|c|c|c|c|}
\hline & BST & ATM & ATS & PEI & NEI & PSCI & NSCI & PEI & NEI \\
\hline BST & $\mathbf{0 . 3 7 9}^{\mathrm{a}}$ & & & & & & & & \\
\hline ATM & $0.261^{\mathrm{b}}$ & $\mathbf{0 . 4 8 8}$ & & & & & & & \\
\hline ATS & 0.311 & 0.188 & $\mathbf{0 . 7 6 0}$ & & & & & & \\
\hline PEI & 0.234 & 0.513 & 0.163 & $\mathbf{0 . 6 1 9}$ & & & & & \\
\hline NEI & 0.000 & 0.051 & 0.006 & 0.012 & $\mathbf{0 . 5 5 8}$ & & & & \\
\hline PSCI & 0.358 & 0.241 & 0.261 & 0.327 & 0.100 & $\mathbf{0 . 4 8 2}$ & & & \\
\hline NSCI & 0.028 & 0.044 & 0.027 & 0.001 & 0.299 & 0.000 & $\mathbf{0 . 5 2 5}$ & & \\
\hline PEI & 0.099 & 0.050 & 0.077 & 0.054 & 0.001 & 0.162 & 0.007 & $\mathbf{0 . 5 9 5}$ & \\
\hline NEI & 0.013 & 0.006 & 0.020 & 0.004 & 0.178 & 0.018 & 0.516 & 0.020 & $\mathbf{0 . 5 9 8}$ \\
\hline
\end{tabular}

${ }^{\mathrm{a}}$ AVE coefficient for the constructs (main diagonal).

${ }^{\text {a }}$ Squared correlation between pairs of latent variables. 
TABLE 5

Results for the re-specified structural model

\begin{tabular}{|c|c|c|}
\hline & $\begin{array}{c}\text { Standard Coef. } \\
\text { (t-value) }\end{array}$ & $\begin{array}{c}\text { Goodness of fit } \\
\text { indices }\end{array}$ \\
\hline $\begin{array}{l}\text { Attitude towards tourism (R2=0.62) } \\
\text { H1: Perception of positive economic impacts } \\
\text { H2: Perception of negative economic impacts } \\
\text { H3: Perception of positive sociocultural impacts } \\
\text { H4: Perception of negative sociocultural impacts } \\
\text { H5: Perception of positive environmental impacts } \\
\text { H6: Perception of negative environmental impacts }\end{array}$ & $\begin{array}{c}0.63(8.46) \\
\text { n.s. } \\
0.19(2.82) \\
-0.21(5.38) \\
\text { n.s. } \\
\text { n.s. }\end{array}$ & $\begin{array}{c}\text { Normed } \chi^{2}=3.11 \\
\text { BBNNFI }=0.90 \\
\text { IFI }=0.91\end{array}$ \\
\hline $\begin{array}{l}\text { Attitude towards tourists }(\mathbf{R 2}=\mathbf{0 . 3 4}) \\
\text { H7: Perception of positive economic impacts } \\
\text { H8: Perception of negative economic impacts } \\
\text { H9: Perception of positive sociocultural impacts } \\
\text { H10: Perception of negative sociocultural impacts } \\
\text { H11: Perception of positive environmental impacts } \\
\text { H12: Perception of negative environmental impacts }\end{array}$ & $\begin{array}{c}0.19(3.42 \\
\text { n.s. } \\
0.42(6.50) \\
\text { n.s. } \\
\text { n.s. } \\
-0.20(4.73) \\
\end{array}$ & $\begin{array}{c}\mathrm{CFI}=0.91 \\
\mathrm{RMSEA}=0.05\end{array}$ \\
\hline $\begin{array}{l}\text { Behavioural support for tourism }(\mathbf{R 2}=\mathbf{0 . 4 4}) \\
\text { H13: Attitude towards tourism development } \\
\text { H14: Attitude towards interaction with tourists }\end{array}$ & $\begin{array}{l}0.38(6.05) \\
0.41(6.60)\end{array}$ & \\
\hline
\end{tabular}

n.s. $=$ non-significant 